

\section{A fotografia a serviço da luta contra a ditadura militar no Brasil}

Photography working on the fight against military dictatorship in Brazil

\section{Paulo César Boni*}

De todos os fotógrafos brasileiros, Evandro Teixeira provavelmente seja o maior exemplo de luta contra a ditadura militar que se instalou no país na década de 1960. Sua luta, sem disparar um único tiro, ecoou, amplificou e repercutiu no Brasil e no mundo. Sua arma? - A câmera fotográfica. Ele foi o único a fotografar o golpe dos bastidores. É dele a fotografia que praticamente simbolizou e condenou o golpe militar, tomada no interior do Forte de Copacabana, na noite do golpe. A imagem, segundo Oswaldo Munteal e Larissa Grandi no livro A imprensa na história do Brasil: fotojornalismo no século XX, "imortalizou o fato, em um momento de luz e sombras, um marco na imprensa e na história do Brasil".

Evandro também foi o único e driblar a marcação cerrada dos militares chilenos, durante o golpe militar que derrubou o presidente Salvador Allende, e fotografar o poeta - Prêmio Nobel de Literatura Pablo Neruda morto. No Chile, como no Brasil, passou por "maus bocados" para documentar o intervencionismo militar nos rumos desses países. Mas não se arrepende. Pelo contrário, se orgulha muito de haver ajudado "a construir a história do Brasil com minha fotografia".

De bem com a vida, premiadíssimo no Brasil e no exterior, Evandro Teixeira concedeu-me essa entrevista quando de sua vinda a Londrina, em outubro de 2011, para palestrar sobre seu trabalho e lutas no fotojornalismo. Simples e acessível, atendeu a todos com a conhecida "paciência de Jó". Humilde, ressaltou que "ninguém é dono da verdade" e destacou que "eu sou apenas mais um aprendiz naquilo que a gente gosta de fazer, que é a fotografia".

\footnotetext{
* Doutor em Ciências da Comunicação pela Universidade de São Paulo (ECA/USP). Coordenador do Mestrado em Comunicação da Universidade Estadual de Londrina (UEL).
} 


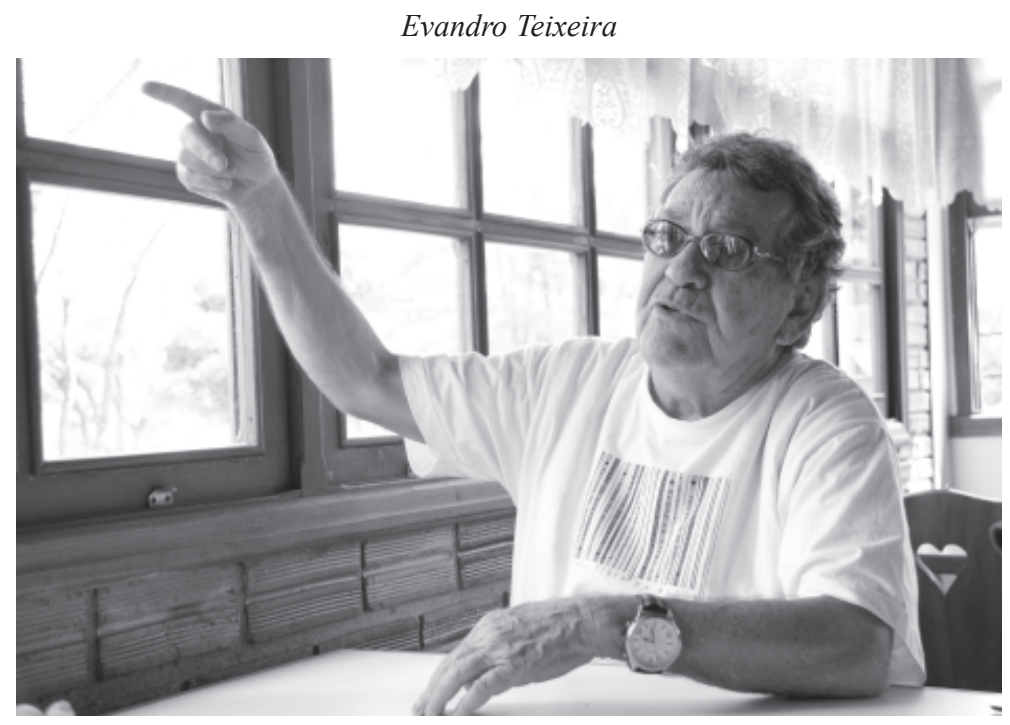

Fotografia: Thiago Coutinho (Londrina, 18.10.2011)

\section{Entrevista}

Paulo Boni - Em uma conversa informal, você lembrou que, antigamente, antes de um repórter entrevistar uma pessoa ele pesquisava tudo sobre ela antes da entrevista. Como eu sou dos tempos de antigamente, pesquisei um pouco sobre sua vida e descobri que você nasceu em três lugares diferentes: Santa Inês, Jequié e Ipiaú. Como é que é isso?

Evandro Teixeira - E ainda está faltando Irajuba (risos). Você deve ter visto isto no documentário Instantâneos da Realidade ${ }^{l}$, não foi? Eu voltei a Irajuba recentemente, com o Paulo Fontenelle, quando fomos produzir o documentário. Fiquei surpreso, pois em frente à casa onde nasci tem um Cristo Redentor, o que me fez achar muita graça. Eu

${ }^{1}$ Evandro Teixeira - Instantâneos da Realidade. Documentário sobre a vida e obra de Evandro Teixeira. Produzido no Brasil, em 2003, sob direção do cineasta Paulo Fontenelle. Duração: 76 minutos. 
saí de lá muito pequeno. Comecei a estudar em Irajuba, meu pequeno vilarejo. Depois fui morar e estudar em Jequié e Ipiaú. Em Jequié tinha o Jornal de Jequié, no qual trabalhei. Lá aprendi muita coisa de jornalismo com o Walter Lessa, que era fotógrafo do jornal. Lá também comprei minha primeira câmera fotográfica, muito simplesinha, e comecei a fotografar. Depois fui estudar em Ipiaú, que tinha o jornal Rio Novo, para o qual eu fazia fotografias. Lá eu comprei uma Polaroid. Com ela eu fotografei muito; já estava até me "achando" fotógrafo. Passei um bom tempo nessas duas cidades e, mais tarde, fui para Salvador. Quando fui para Salvador eu já era "fotógrafo" e fui estagiar no Diário de Notícias, que era do grupo dos Diários Associados. Comecei fazendo estágios como fotógrafo no interior.

Paulo Boni - Isso com 15 anos de idade, mais ou menos.

Evandro Teixeira - 12 anos, 15 anos, por ai. Na realidade eu aprendi a fotografar mesmo foi com o José Medeiros, um dos maiores nomes da fotografia brasileira, que depois se tornou cineasta. Ele tinha um curso de fotografia na revista $A$ Cigarra, que era de $O$ Cruzeiro e eu comecei a estudar por correspondência com o José Medeiros. Antes disso, porém, o que eu sabia de fotografia havia aprendido com o Teotônio Rocha, um fotógrafo clássico, que fazia fotografias lindíssimas, muito bem iluminadas, com sua câmera chapa de vidro e tal. Quando fui morar em Salvador, também para estudar, conheci um fotógrafo importante, o Teotônio Rocha, que era tio do Glauber Rocha. Aprendi muito de fotografia com ele também. Lá em Ipiaú eu tinha um amigo, quase um irmão, o Mapin, que era compositor. Depois calhou de morarmos juntos em Salvador e ele sempre dizia que eu tinha que ir para o Rio de Janeiro. E eu sempre retrucava: "Pô, Mapin, como é que eu vou para o Rio de Janeiro? Eu não sou nada, não conheço nada, não conheço ninguém, sou apenas um fotógrafo da roça, do meio do mato, um aprendiz..." E ele insistia: "Evandro, se você quer trabalhar com jornalismo tem que ir para o Rio de Janeiro, a capital cultural do país. Lá estão os maiores jornais, as maiores revistas, as rádios, tudo. Pô, 
cara, você foi aluno do José Medeiros. Você tem que ir para o Rio de Janeiro."

Paulo Boni - Perdão, Evandro, me deixa retomar uma informação para não perder o fio da meada... Quando você fez o curso do José Medeiros você estava em Salvador?

Evandro Teixeira - Sim, em Salvador. Mas eu fiz o curso por correspondência.

Paulo Boni - Fotografia por correspondência?!

Evandro Teixeira - Sim, por correspondência, na revista $A$ Cigarra. Foi assim que eu comecei. Havia vários cursos, com vários professores, mas eu escolhi o curso com o José Medeiros.

Paulo Boni - Algo parecido com o antigo Instituto Universal Brasileiro?

Evandro Teixeira - Exatamente isso. Mas o processo era muito didático. Aprendi a fazer boas fotografias nesse curso por correspondência.

Paulo Boni-E sua vinda para o Rio de Janeiro?

Evandro Teixeira - Um dia eu tomei coragem. O Mapin me disse que tinha dois amigos no Rio de Janeiro. Um era dos Diários Associados. O Diário da Noite, O Cruzeiro, a TV Tupi e a Rádio Tupi eram todos do Assis Chateaubriand. O amigo do Mapin era diretor de redação do Diário da Noite, um baiano, como nós. O Mapin fez uma carta para eu apresentar a ele quando chegasse ao Rio de Janeiro. Aí tomei coragem. Falei com os meus pais e eles me mandaram um dinheirinho. Comprei uma passagem aérea e me mandei para o Rio de Janeiro. Foi uma mudança radical: muita agitação, barulho, zoeira, confusão. Mal deu três dias e eu já queria voltar para a Bahia. Fui morar na pensão de uma senhora que alugava quartos, em Copacabana. O Diário da Noite ficava na Praça Mauá. E eu fui lá procurar o amigo do Mapin, o Ariston Andrade, secretário de redação do O Jornal, 
que me recebeu muito bem. Fui de bonde. Era lindo andar de bonde, aquela coisa bucólica e tal. O amigo do Mapin me apresentou ao editor de fotografia do jornal, o Ângelo Regatto, um italiano, uma figura maravilhosa. Até hoje sou muito agradecido ao Ângelo. Nesse prédio, na rua Sacadura Cabral, na Praça Mauá, ficavam dois jornais: $O$ Jornal, no quarto andar, e o Diário da Noite, no terceiro andar. A revista $O$ Cruzeiro ficava em outro prédio, em uma rua próxima. Os fotógrafos de $O$ Cruzeiro, naquela época, só saíam com segurança, eram as vedetes, eram mitos... Bom, voltando ao nosso caso, o amigo do Mapin me apresentou ao Ângelo, que me levou ao departamento fotográfico, no terceiro andar, onde ficava o Diário da Noite. Ele disse que me daria uma oportunidade de fotografar. Na hora eu tremi e lhe disse: "Eu não sou fotógrafo, sou aprendiz, só quero fazer um estágio." Ai ele me apresentou ao diretor geral, um cara linha dura, de paletó e gravata. Antigamente a relação subordinado/chefe era uma coisa de muito respeito, muito formal, doutor prá lá, doutor prá cá. O diretor geral falou para o Ângelo: "Como nosso fotógrafo vai se aposentar mesmo e o seu amigo quer trabalhar, vamos colocá-lo como santo casamenteiro." Santo casamenteiro era o fotógrafo que cobria casamentos. O Diário da Noite tinha uma página inteira dedicada à cobertura de casamentos. Mas não era como as colunas sociais de hoje; era uma coisa simples, o cara entrava na igreja, fazia uma fotografia do casamento que estava acontecendo e o jornal publicava. Em linhas gerais, era uma atribuição sem importância, por isso me colocaram nessa função. O diretor linha dura virou para mim e disse: "Então, baiano, já que você quer ser estagiário, será o santo casamenteiro do jornal." E continuou: "Mas eu quero deixar claro uma coisa: pode ser rico, pode ser pobre, não importa. O que eu não quero é que você fotografe preto, entendeu?" "Sim senhor, doutor", respondi.

Paulo Boni - Hoje em dia ambos teriam sido mais cautelosos...

Evandro Teixeira - Nem me fale... Bom, o fato é que me passaram uma lista de igrejas e eu comecei a ligar para achar algum 
casamento. Liguei, liguei, liguei e nada. No final da tarde, haveria um casamento na Gávea. Nossa, que alívio! Parti para lá imediatamente. Quando entrei na igreja, me deparei com uma loira, tipo alemã, casando com um negro de cabelos black power, aqueles cabelões armados, entendeu? Pensei: “E agora?" Bem, preparei minha Rolleiflex 6x6, filme $120 \mathrm{~mm}$, e cliquei, afinal era o único casamento do dia e eu não poderia, no meu primeiro dia de estágio, voltar de mãos abanando. Voltei à redação e entreguei o filme para o laboratorista, um português muito engraçado, de apelido (creio que era o sobrenome dele) Vilar. Eu expliquei a ele que era uma loira casando com um negro. Ele riu às gargalhadas $\mathrm{e}$ disse para eu ficar tranquilo que o negro iria ficar branco na fotografia. Passado um tempo, ele me entregou uma cópia da fotografia e o cara havia ficado branco mesmo. Aí eu sentei na máquina de escrever e preparei a legenda: “Casou-se ontem na igreja da Gávea, o Sr. José Joaquim da Silva (sei lá o nome do cara) com dona Maria Josefa e tal", dobrei a lauda e coloquei a fotografia dentro e, morrendo de medo, entreguei-a à secretária do poderoso chefão.

Paulo Boni-E ninguém percebeu?

Evandro Teixeira - O chefão percebeu e ficou uma fera. Depois de entregar a fotografia para a secretária, voltei para a minha sala. $\mathrm{O}$ Ângelo passou por lá e perguntou se eu havia entregado a fotografia. Disse que sim e ele respondeu que, então, estava bom. Tentei mostrar uma cópia da fotografia para ele, mas ele nem olhou para ela. Perguntou se eu havia feito a legenda. Disse que sim e, novamente, ele respondeu que estava bom. Lá pelas 20h15, me lembro como se fosse hoje, o telefone tocou na sala do Ângelo. Ele atendeu. Era o poderoso chefão, que o chamou para comparecer imediatamente à sua sala. Chegando lá, o diretor mostrou a fotografia ao Ângelo e, irritado, falou: "Olha essa fotografia. Eu falei para esse merda desse baiano que eu não queria preto." O Ângelo tentou argumentar alguma coisa, mas o diretor estava mesmo zangado: "Vai se ferrar, caramba! Até você está querendo me enganar. Olha o cabelo do cara. Você acha que um branco teria um 
cabelo desses?" E quis logo encerrar a conversa: "Manda esse merda desse baiano burro embora." E o Ângelo: "Mas, doutor, ele é apenas um moleque, um simples estagiário." "Mas é burro", retrucou o diretor, "manda ele de volta para a Bahia, não quero esse cabra aqui porque ele é burro", encerrou a conversa.

\section{Paulo Boni - E o Ângelo fez o quê?}

Evandro Teixeira - Ele me deu a maior dura. Disse que eu havia feito merda e traído a confiança dele. Depois ele amoleceu um pouco. Pediu para eu ficar uns quinze dias sem aparecer, até a "fera amansar um pouco". Estávamos no começo do ano e ele falou para eu sumir por umas duas semanas, mas voltar para trabalhar no carnaval. Fiz exatamente o que ele falou. Sumi por uns dias e voltei para trabalhar no carnaval.

Paulo Boni - E nesses quinze dias, o que você fez?

Evandro Teixeira - Bom, eu precisava ganhar dinheiro. Então eu procurei o outro amigo recomendado pelo Mapin, o Dr. César Augusto, que morreu há pouco tempo. Ele também era uma figura muito engraçada. Contei para ele que tinha vindo para estagiar como fotógrafo no Diário da Noite, mas que eu precisava ganhar dinheiro, porque o pouco que eu havia trazido da Bahia não iria dar para viver muito tempo no Rio de Janeiro, e coisa e tal, e que eu precisava arranjar um emprego. Ele tinha um amigo que era diretor de uma construtora e me disse: "Vou arranjar um emprego para você; fique tranquilo." O sujeito ligou para seu amigo na construtora e pronto: arranjou-me um emprego. Não era lá grande coisa, mas dava para pagar a pensão.

Paulo Boni - E depois de quinze dias você voltou para o Diário da Noite?

Evandro Teixeira - Sim, voltei. O Ângelo me recebeu e me confiou uma nova oportunidade. Eu fui cobrir o baile do Municipal. Tiveram que alugar um smoking para eu entrar, pois era traje a rigor. $\mathrm{O}$ Ângelo me alertou: "Baiano é o seguinte: o baile é bonito, mas depois 
tem o mais importante, o desfile de fantasia. Precisamos de boas fotografias. Vê se não faz merda dessa vez, hein?!' E lá fui eu, portando uma Leica. Nossa! O baile era lindo, uma coisa maravilhosa, fiquei emocionado. Aquilo era uma emoção só. O baile era embaixo, no primeiro andar. $\mathrm{O}$ desfile de fantasias era no segundo andar. Desfilavam o Evandro de Castro Lima, o Clóvis Bornay e um monte de mulheres famosas. Esse desfile era da maior importância. Era a coisa mais linda. Num determinado momento, as pessoas que desfilavam pela passarela chegavam até a porta do Teatro Municipal, mas no segundo andar, onde há uma janela grande. A passarela saía pela janela cerca de meio metro para frente, para que as pessoas do lado de fora pudessem ver. A Cinelândia ficava lotada de gente para ver os desfiles. Era aquele monte de gente admirando, batendo palmas, coisa linda mesmo. O baile começou às 22h00. Quando deu $01 \mathrm{~h} 00$ da madrugada, o locutor anunciou: "Atenção senhoras e senhoras e senhores, vai começar o desfile de fantasias." Aí eles arriavam uma passarela para você subir e acompanhar o desfile. Só que eu fiquei nervoso, confuso no meio de tanta novidade e acabei não subindo. Ou seja, quebrei a cara, não consegui fotografar o desfile, resumindo: fiz merda de novo.

Paulo Boni-E isso, claro, decretou o fim do seu estágio no Diário da Noite?

Evandro Teixeira - É claro que eu pensei: "Estou lascado!" Quando cheguei à redação, na manhã seguinte, o Ângelo me perguntou: "Cadê as fotos do desfile?" E eu respondi que não as tinha. Expliquei para ele o que havia acontecido e ele ficou furioso. Disse que se o poderoso chefão ficasse sabendo, desta vez ele estaria ferrado também. Então, para salvar a minha pele e a dele, falou: "Vamos lá na redação de O Cruzeiro pegar umas fotos e fazer de conta que elas são suas." Chegamos lá, ele explicou a situação, pegou algumas fotografias e pediu para que o responsável pelo arquivo não as carimbasse, pois era norma de $O$ Cruzeiro colocar um carimbo atrás das fotografias, onde eram anotados os dados do evento, o nome do fotógrafo, a data da tomada e 
coisas do gênero. Ele entregou as fotografias para o chefão e não contou nada para ele. Depois, quando a coisa estava um pouco mais calma, ele voltou novamente sua ira para cima de mim: "Tu é um merda mesmo, hein baiano!? Não é porque eu gosto de você, porque sou amigo do Mapin, que eu vou quebrar todos os seus galhos. Olha, amanhã tem o desfile das escolas de samba na avenida, é tua última chance. Se você quebrar a cara de novo, pode pegar um pau-de-arara e voltar para a Bahia."

\section{Paulo Boni - Dessa vez você se safou bem?}

Evandro Teixeira - Graças a Deus! O desfíle das escolas de samba foi na Avenida Rio Branco. Dessa vez eu fui lá e fiz um bom trabalho, um ensaio muito bom. Ai ele se empolgou, foi até a sala do chefão, mostrou as fotografias para o homem e disse: "Não te falei que o baiano é bom? Eu trouxe o baiano de volta." O chefão gostou das fotografias e me deu uma chance de atuar como fotógrafo. Aí começou minha história no fotojornalismo carioca, no fotojornalismo brasileiro, no Diário da Noite, nos Diários Associados. Fiquei lá até 1960, 1961.

Paulo Boni - E como você foi para o Jornal do Brasil?

Evandro Teixeira - O Alberto Dines, um dos maiores editores do jornalismo brasileiro, que havia fundado o Diário da Noite e posteriormente comandado sua transição para o formato tablóide, foi convidado para dirigir o Jornal do Brasil e me chamou para ir com ele. O JB era a estrela do jornalismo brasileiro, era onde trabalhavam nomes como Carlos Drumond de Andrade, Otto Lara Resende, Antonio Callado, Sueli Ventura, Arthur Xexéu e outros grandes nomes do jornalismo. A fotografia era a elite do jornal. Para se ter uma ideia, no $J B$ o fotógrafo ganhava mais que o repórter de texto. Eu queria ir, mas fiquei com medo. Nessa época, a revista $O$ Cruzeiro, que era o expoente do fotojornalismo brasileiro, com grandes nomes como o José Medeiros, o Indalécio Wanderlei, o Geraldo Viola e outros, estava em decadência. 
Paulo Boni - O Jean Manzon já havia saído de O Cruzeiro nessa época?

Evandro Teixeira - O Jean Manzon já havia saído. Isso foi na década de 60 e o Manzon, que começou na década de 40 na revista, já havia saído. Eu decidi não ir para o Jornal do Brasil. Agradeci muito ao Alberto Dines e ao Edílson Martins, que era o editor de fotografia, o convite, mas argumentei que ainda não me sentia preparado para encarar o $J B$. Fiquei um ano no Diário da Noite. Depois me chamaram para a Mundo Ilustrado, que era uma revista semanal belíssima, que pertencia ao Diário da Noite. Achei melhor dar um tempo, ganhar um pouco mais experiência e coisa e tal. Fiquei dez meses na Mundo Ilustrado e só aí eu fui para o Jornal do Brasil, no final de 1962. Fiquei lá de 1962 até agosto de 2010, quando o jornal impresso deixou de circular, ou seja, foram 37 anos de Jornal do Brasil. O JB, de fato, valorizava a fotografia. A maioria das estrelas do fotojornalismo brasileiro estava lá. Era uma honra, um orgulho ser fotógrafo do $J B$. Nós, fotógrafos, tínhamos até uma página gráfica, no Caderno $\mathrm{B}$, intitulada Onde o Rio é mais carioca. Você tinha liberdade de sair às ruas, se pautar, criar suas matérias e ensaios fotográficos, e tudo sem flash ou fotômetro. Flash era proibido no Jornal do Brasil. O Alberto Ferreira, que foi um dos maiores editores de fotografia do Brasil, proibia. Quando o jornal comprava novos equipamentos, a primeira coisa que ele fazia era tirar o flash e o fotômetro. Você tinha que usar o olhômetro, tinha que criar, tinha que saber fotografar.

Paulo Boni- Era o olhômetro e a luz natural.

Evandro Teixeira - Luz natural o tempo todo. Anão ser em casos extremos, oflash era proibido.

Paulo Boni - Evandro, eu quero focar essa nossa conversa no seu trabalho durante o regime militar, a ditadura militar no Brasil, instituída em 1964, o Ato Institucional número 5, o AI-5, de 1968, mas antes eu gostaria 
de esclarecer outra dúvida. Em minhas pesquisas eu achei duas datas de nascimento...

Evandro Teixeira-É verdade. Eu também já vi isso (risos). Mas não fui eu que falei isso, não. Pergunte que eu respondo.

Paulo Boni-A data de nascimento correta?

Evandro Teixeira - A data de nascimento correta é 25 de dezembro de 1935.

Paulo Boni - Ou seja, você está com 76 anos?

Evandro Teixeira-É, mas eu não me acho com essa idade toda, não, porque, Graças a Deus, eu tenho uma disposição danada, uma vitalidade incrível, sempre gostei de correr muito, e continuo correndo. Acho que minha mãe errou a minha data de nascimento... Agora, nesse momento, estou com um problema no joelho, estourei o menisco, mas já estou tratando. O problema é que recuperar demora um pouco.

Paulo Boni - Nada que o Runco ${ }^{2}$ não resolva.

Evandro Teixeira - Nada que ele não dê jeito. Inclusive, já tenho uma consulta agendada. Mas tem confusão quanto a minha idade mesmo. Recentemente, uma moça, que está fazendo mestrado em Nova Iorque, me mandou um material para eu conferir e ela dizia que o ano de meu nascimento era 1945, pois ela havia lido em algum lugar que era 1945.

Paulo Boni -Êpa! Estão escrevendo uma dissertação sobre você?

Evandro Teixeira - Parece que sim. Ela escolheu um fotógrafo brasileiro para ser o tema de seu trabalho de mestrado e eu tive a honra de ser escolhido. Aí eu corrigi a data de nascimento, mas algumas coisinhas, e devolvi o trabalho para ela. Aproveitei para mandar também uma cópia do documentário Instantâneos da Realidade. Ela me respondeu dizendo que iria exibi-lo para seus colegas de sala e depois deixaria uma cópia na biblioteca da universidade, legal né?!

${ }^{2}$ Dr. José Luiz Runco, médico da seleção brasileira de futebol e amigo de Evandro Teixeira. 
Paulo Boni - E por falar em universidade, você é formado em algum curso superior?

Evandro Teixeira - Não. Eu comecei a cursar belas artes, na Escola Nacional de Belas Artes, mas não terminei.

Paulo Boni - Bom, então vamos ao nosso foco, o período da ditadura militar. Você se sente incomodado em falar desse período?

Evandro Teixeira - Não, muito pelo contrário. Fui um dos fotógrafos que mais retratou aqueles momentos terríveis no Rio de Janeiro. Não só no Rio de Janeiro, no Brasil todo. Também tive oportunidade de fotografar o golpe militar no Chile, aliás, fui o único brasileiro a fotografá-lo. Vou falar um pouco dessa experiência no Chile, depois eu volto para falar do Brasil. Eu tive o privilégio, a honra, a glória e, ao mesmo tempo a tristeza, de haver fotografado a morte do poeta Pablo Neruda, Prêmio Nobel de Literatura. Eu sempre digo que foi um misto de alegria e tristeza. Alegria por ter sido o único fotógrafo/jornalista do mundo a vê-lo e fotografá-lo morto, por documentar aquele momento terrível do Chile. Tristeza por presenciar a finitude de um mito e todo o aparato militar para que ele não fosse decentemente velado e sepultado.

Paulo Boni - Você estava no Chile a trabalho nesse momento?

Evandro Teixeira - Sim, eu havia ido cobrir o golpe militar ${ }^{3}$ de 11 de setembro de 1973, que derrubou o presidente Salvador Allende e alçou o general Augusto Pinochet ao poder. Foram momentos terríveis que eu passei por lá. Muitos jornalistas morreram nessa cobertura. Havia jornalistas do mundo todo, nós éramos mais de mil jornalistas no Chile, mas fui o único a fotografar o Neruda morto.

${ }^{3}$ Golpe de Estado ocorrido no Chile, em 11 de setembro de 1973, que destituiu do poder o presidente Salvador Allende e encerrou o período de constitucionalidade democrática do país. Quem comandou o golpe foi o general Augusto Pinochet, que se autoproclamou presidente. 
Paulo Boni - As condições de trabalho para os jornalistas eram boas?

Evandro Teixeira-Nada. Era terrível. Os militares nos cerceavam o tempo todo. Os jornalistas ficavam no Hotel Carrera, em frente ao Palácio La Moneda. Nós trabalhávamos no hotel e fotografávamos pelas janelas, porque era proibido fotografar nas ruas de Santiago. Depois veio o toque de recolher, das $18 \mathrm{~h} 00$ às 06h00. Se você estivesse nas ruas, fosse homem, mulher, velho ou criança, eles fuzilavam primeiro e perguntavam depois, uma loucura! Assim, a gente ficava no hotel sem ter o que fazer, comendo, bebendo e batendo papo entre jornalistas. Uma noite, fui jantar no terraço do hotel - o restaurante ficava no terraço - e conheci uma senhora paulista, esposa de um adido militar do Chile no Brasil, que tinha sido convocado para o golpe. Nesta, e nas noites seguintes, passei a dividir a mesa com ela e com o embaixador do Uruguai.

Paulo Boni - Você conseguiu alguma informação importante com ela ou com o embaixador?

Evandro Teixeira - Sim, consegui uma informação importante sobre o Pablo Neruda. Naquele momento, o Salvador Allende estava morto. O Augusto Pinochet não recebia ninguém. Ou seja, a mais importante personalidade do Chile, possível de ser encontrado, era o Pablo Neruda, mas ninguém sabia nada dele. Essa senhora me disse que ninguém iria encontrar o Neruda porque ele estava confinado na Isla Negra. "Mas tem um detalhe", disse ela, "ele está mal de saúde e será trazido para o Hospital São José, em Santiago". Vá ao hospital amanhã, continuou ela, e procure pelo diretor (não me lembro o nome agora), eu sou amiga dele e ele irá recebê-lo. Deu-me um cartão de visita para apresentar ao diretor e, no dia seguinte, lá fui eu.

Paulo Boni-E o marido dela, o adido militar?

Evandro Teixeira - Até hoje não sei se ele sabe que ela me passou essa informação. Mas ela era paulista, gente nossa. Ela estava morando no hotel enquanto o marido estava lá, envolvido até o pescoço 
no golpe militar. Eu fui até o hospital. O médico diretor me recebeu e confirmou que o Neruda havia dado entrada no hospital, acompanhado de sua esposa, a dona Matilde. Eu me apresentei como amigo dele. Disse ao médico que já o havia fotografado no Brasil, ao lado de Jorge Amado e coisa e tal. O médico respondeu que não confiava muito em nós, jornalistas, não.

Paulo Boni - E ele permitiu você ver e fotografar o Neruda?

Evandro Teixeira - Permitir, permitir, não permitiu. Mas eu insisti dizendo que era amigo da dona Matilde. Aí ele cedeu um pouco: abriu uma portinhola e eu pude ver a dona Matilde. Aproveitei esse instante e disse para ela: "Oi, dona Matilde, sou o Evandro, o fotógrafo do Jorge Amado. Meus sentimentos, melhoras para o mestre." Já ia por a mão na câmera, mas o médico não permitiu, me puxou para o lado e disse: "Muito bem, Evandro, agora o senhor vai embora e depois eu the passo o próximo boletim médico do poeta. Ele sairá às $22 \mathrm{~h} 00$ e nessa hora o senhor já estará no hotel com os outros e eu o passo para todos." Fazer o que, né?

Paulo Boni - Mas, pelo jeito, você "furou" o boletim médico...

Evandro Teixeira - Quando deu $22 \mathrm{~h} 00$ e não apareceu boletim nenhum, liguei para o médico e perguntei como estava o mestre Neruda. Ele me respondeu: "Meu querido amigo, lamentavelmente, o professor faleceu agora há pouco." Nem dormi aquela noite. Às 06h00 levantei, tomei café e fui para o hospital. Escondi minha Leica debaixo da camisa. A Leica é ótima para esse tipo de coisa, não faz barulho, é só colocar uma grande angularzinha e pronto. Quando cheguei ao hospital pensei: eles não vão me deixar entrar. Então fiquei rodeando por ali, quando achei uma porta aberta no fundo do hospital, entrei e pensei: "Seja o que Deus quiser." Quando cheguei ao final de um corredor, lá estava o corpo do Pablo Neruda jogado numa sala qualquer, e a dona Matilde ao seu lado. Primeiro fiz uma fotografia sem eles perceberem. Depois eu me dirigi à dona Matilde e disse: "Eu sou o fotógrafo do Jorge Amado, 
a senhora está lembrada de mim?" Joguei essa e ela entrou na jogada. “Lembro, sim, meu filho. E o Jorge, como é que ele está?” Lembrava coisa nenhuma. Ela só disse isso para ser gentil. Eu respondi que o Jorge Amado ia bem, lhe dei os meus pêsames, disse que a morte do poeta era uma perda lamentável e pedi permissão para fotografá-lo. Ela estava chorando muito, mas disse "tudo bem, meu filho, pode fotografar, afinal o Jorge Amado é um irmão para nós". E era um irmão mesmo, eles eram muito amigos. Fiquei por ali, fotografando. Daí a pouco eles vieram e levaram o corpo para prepará-lo e eu fotografando tudo. Começaram a arrumar o corpo, passar formol, aquelas coisas todas, e eu fotografando. Terminaram o preparo e colocaram o corpo num caixão, e eu fotografando. Dali ele foi levado para sua casa, que ficava no alto de uma colina, e eu fotografando tudo.

Paulo Boni - Eu tive a oportunidade de conhecê-la, pois hoje ela é uma atração turística de Santiago.

Evandro Teixeira - Só que naquela época existia um riachozinho em frente à casa. Eu pedi para dona Matilde permissão para acompanhá-la na condução do corpo até à casa. Ela, muito gentil, autorizou. Só ela e alguns amigos muito próximos estavam conduzindo o corpo. Quando chegamos ao alto da colina, o riachozinho havia se transformado num rio. Os militares, de sacanagem, romperam a represa acima da casa e inundaram o vilarejo todo para evitar que o caixão com o corpo passasse. Tivemos que improvisar uma ponte com tábuas e pedaços de madeira. Eu tenho tudo isso registrado. Quando chegamos, a primeira pessoa a entrar foi dona Matilde. Os militares haviam literalmente destruído a casa, quebrado tudo, jogado tudo ao chão. E eu fotografei aquilo tudo, só eu, mais ninguém. Aos poucos foram chegando alguns amigos. Permanecemos lá, velando o corpo e em vigília. Na manhã seguinte, por volta das $10 \mathrm{hs}$, saímos com o corpo em direção ao cemitério. Fotografei a saída do corpo, coberto com a bandeira do Chile, pela ponte improvisada. Fomos para o cemitério cantando o hino internacional. E o povo foi chegando e engrossando o cortejo. O Pinochet, malandro, para 
esvaziar o enterro do Neruda, convocou uma coletiva de imprensa no mesmo horário. Eu pensei: "Dane-se o Pinochet." Optei por ficar no enterro do Neruda. Meu amigo, quando chegamos ao cemitério, foi a coisa mais linda do mundo. Lá estava toda a imprensa, pois a notícia havia vazado. As pessoas estavam lá declamando as poesias de Neruda. Foi a coisa mais linda; eu chorei de emoção. Subi num túmulo e fotografei o cerimonial todo, a esquife com o corpo entrando na sepultura, tudo, tudo. Tenho tudo isso arquivado até hoje.

Paulo Boni - Depois disso você retornou ao Brasil?

Evandro Teixeira - Não imediatamente. Fiquei um pouco mais no Chile, fotografando o desenrolar do golpe militar. Além das coisas banais, fotografei mais dois momentos importantes.

\section{Paulo Boni-Primeiro?}

Evandro Teixeira - No Chile estava faltando carne bovina. Só havia carne de galinha e peru para a população. Uma tarde eu estava saindo de uma entrevista coletiva com o ministro das Relações Exteriores, que era um almirante, e me dirigindo para o hotel para revelar os filmes e enviar as fotografias por telefoto, quando vi um caminhão de carne bovina sendo descarregado no Ministério da Defesa, que ficava do outro lado da rua. Não tive dúvida, comecei a fotografar tudo. Enquanto fotografava, pensava: "Falta carne para a população, mas não para esses milicos safados..." Mas, para meu azar, vinha uma patrulha atrás de mim, e eu não vi. Os milicos me pegaram e me levaram, empurrando com baioneta, me cutucando e tudo. Eu pressenti que boa coisa não seria então tratei de, sutil e rapidamente, tirar o filme da máquina e guardá-lo no meio das minhas coisas. Chegamos ao quinto andar do Ministério da Defesa, onde fui apresentado a um chefe de seção, um coronel, que foi logo querendo saber por que eu estava fotografando a entrega de carne. Eu inventei a maior lorota. Disse que trabalhava para o Jornal do Brasil e que nós apoiávamos o golpe, inclusive havia militares nossos ajudando a acabar com os comunistas do Chile. Disse que o jornal para o qual eu trabalhava 
era de uma condessa muito católica, que não podia nem ouvir falar em comunista, e fui inventando lorotas. Disse es Exteriores, que era um almirante, e me dirigindo em direinistro das Relaio. seu lado.Por que estava fotografando apenas por curiosidade, pois jornalista é um bicho curioso por natureza, mas que ele poderia ficar com o material, revelar o filme que não iria encontrar nada comprometedor. Por fim, pedi ao coronel que me liberasse, pois já era quase $18 \mathrm{~h} 00$ e depois do toque de recolher eu não poderia sair às ruas para voltar ao hotel. E ele ficava me enrolando, me enrolando. Quando faltavam 15 minutos para as $18 \mathrm{~h} 00$ eu disse: "Coronel, pelo amor de Deus, me deixa ir embora, se não eu não conseguirei chegar ao hotel antes do toque de recolher." Ele riu ironicamente e disse que sair às ruas depois das $18 \mathrm{~h} 00$ "és mui peligroso". Então eu sugeri que ele mandasse uma patrulha me escoltar até o hotel, porque eu precisava passar uma fotografia para o jornal e coisa e tal. Ele disse que não. E eu retruquei: “Então eu estou preso aqui?’” Ele disse que não. E eu insisti: "Se o senhor não me deixa sair, não autoriza uma patrulha me escoltar até o hotel e me mantém aqui, então eu estou preso." Ele insistia que não, que eu era convidado dele. Está bem, fazer o quê? Passei a noite toda lá, sentado num banco, sem dormir, tomando café. Cabra filho de uma égua!

\section{Paulo Boni - E o segundo momento?}

Evandro Teixeira - $\mathrm{O}$ segundo momento importante foi o reconhecimento de corpos no necrotério. A gente tinha como base o escritório da UPI (Unidet Press International), hoje AP(Associated Press), com a qual o Jornal do Brasil tinha convênio. AUPI havia recebido uma denúncia de que estariam chegando corpos de vítimas dos confrontos do golpe na ala B do necrotério de Santiago. O Ministério da Defesa do Chile convocou os familiares dos mortos para irem até o necrotério reconhecer os corpos. O processo era meio burocrático: os familiares tinham que ir até o Ministério da Defesa e apanhar uma autorização para entrar no necrotério. $\mathrm{O}$ diretor da UPI até pensou em infiltrar um jornalista, mas ficou receoso e desistiu da ideia. Eu disse para ele que poderia ir. Ele me perguntou: "Você é maluco?". Respondi que não e confirmei que gostaria 
de ir até o necrotério. Então eles inventaram um nome qualquer para mim e providenciaram uma autorização no Ministério da Defesa e, claro, me alertaram que eu deveria ficar o tempo todo de boca fechada, pois se eu falasse uma palavra sequer e os milicos descobrissem que eu não era chileno, eu seria preso ou morto. Chegando lá, preparei minha Leica para foco de dois a três metros, velocidade do obturador em 125 e diafragma em f 5,6, escondi-a debaixo da camisa e memorizei: ala B. Apresentei a carta para um recepcionista, morrendo de medo e sem falar nada, claro, e os milicos me escoltaram pelo necrotério Eu estava nervoso, chegava a suar frio. Enquanto andava pelos corredores, vi que eles estavam descarregando mais corpos, descarregavam corpos como se fossem sacos de lixo. Pensei em roubar uma fotografia, mas no momento em que toquei a mão na barriga, onde estava escondida a câmera fotográfica, levei uma coronhada de um milico que estava atrás de mim. Cai gemendo de dor. Ainda bem que gemido não tem língua, se não os milicos teriam me descoberto. Enfiei a mão no bolso, peguei a autorização do Ministério da Defesa e mostrei-a para o milico. E ele próprio me acompanhou à ala de reconhecimento de corpos, sempre atento a qualquer movimento. Entrei, olhei, fiz sinal com a cabeça que não havia reconhecido ninguém e ele me acompanhou até a saída. Dessa vez, quebrei a cara: vi tudo e não fotografei nada. Senti-me duplamente triste. Primeiro pela barbárie que presenciei; segundo por não ter conseguido fazer nenhuma fotografia.

Paulo Boni-Quanto tempo você ficou no Chile?

Evandro Teixeira - Uns 20 dias.

Paulo Boni - Em 20 dias deu para avaliar se a repressão do Chile era maior que a do Brasil?

Evandro Teixeira -A repressão no Chile foi 100 vezes maior que a do Brasil. Eu tive a oportunidade de entrar - e fotografar - no Estádio Nacional, que era onde os militares chilenos mantinham os presos. Eles próprios, os militares, nos levaram no estádio, porque queriam mostrar que os presos estavam sendo bem tratados. Mentira! A maioria daqueles 
presos foi morta. Os porões do Estádio Nacional eram utilizados para tortura e como depósito de mortos que a ditadura militar não queria que fossem encontrados. Foi uma carnificina horrível. Você assistiu Missing?

Paulo Boni-Missing ${ }^{4}$, do Costa-Gravas?

Evandro Teixeira - Esse mesmo. Esse filme é uma coisa maravilhosa, é um retrato fiel do que aconteceu no Chile. Eu afirmo isso com convicção porque eu vi, eu estava lá. Os militares só mostraram para os jornalistas os presos que estavam no gramado. Nos porões a história era outra. Eles mataram muita gente e enterravam (escondiam) os corpos em uma parede, para nunca serem encontrados. Aquilo era um cenário de horror, na saída consegui roubar uns três ou quatro fotogramas e me piquei, mas isso foi uma loucura. O clima era muito tenso no Chile pós-golpe militar. Mas sua pergunta é pertinente, porque no Chile houve muito mais repressão e muito mais mortes que no Brasil. Só vendo Missing para poder avaliar. Ele é um retrato fiel, uma história real contada pelo pai de um jornalista americano, casado com uma chilena, que estava morando e trabalhando no Chile na época da repressão. Missing é uma história realíssima, não é ficção.

Paulo Boni-E o seu trabalho durante a repressão militar no Brasil?

Evandro Teixeira - Eu era contra o golpe militar. Eu tinha meus ideais políticos. Eu não fui assim um Vladimir Herzog ${ }^{5}$, um João Saldanha ${ }^{6}$, nem estudante eu era à época, para ficar subindo em palanque e gritando,

\footnotetext{
${ }^{4}$ Filme de 1982 sobre o Golpe de Estado no Chile e suas repercussões para os direitos humanos. Dirigido por Costa-Gravas, com duração de 122 minutos, o filme ganhou o Oscar de melhor roteiro adaptado em 1983. No Brasil o filme recebeu o título de Missing - Desaparecido, um grande mistério.

5 Jornalista morto, em 25 de outubro de 1975, nos porões da ditadura militar no Brasil. Os militares inventaram a versão de que ele havia se suicidado. Virou um símbolo na luta contra a ditadura militar e pelos direitos humanos. Desde 1977, para homenageá-lo, existe o Prêmio Vladimir Herzog de Anistia e Direitos Humanos para o jornalismo brasileiro. Anualmente, onze categorias são premiadas: Livro-reportagem, Artes, Fotografia, Jornais, Literatura, Rádio, Revista, Teatro, TV - documentário ou especial, e TV - jornalismo diário e imagem de TV.

${ }^{6} \mathrm{Um}$ dos mais ilustres comunistas brasileiros. Jornalista e técnico de futebol morreu em Roma (Itália), em 1990
} 
então eu não poderia deixar de documentar tudo aquilo. Foi a minha forma de lutar contra a ditadura.

Paulo Boni - Você era - ou ainda é - comunista?

Evandro Teixeira - Não. Eu nunca fui filiado, era apenas um admirador, mas também não cheguei a ser fanático. Eu achava que ser comunista ou lutar por ideais de liberdade, direitos humanos e coisa e tal era função de outras pessoas. A minha função era lutar com a arma que eu dispunha, ou seja, uma câmera fotográfica. E foi o que fiz: usei minha câmera fotográfica para lutar contra a ditadura militar, pelo menos eu tive a coragem de documentar e mostrar a realidade daquele momento político do Brasil.

Paulo Boni - Você foi o único que fotografou os bastidores do Forte de Copacabana no dia do golpe. Como conseguiu autorização para entrar?

Evandro Teixeira - Que autorização, que nada. Eu tinha um amigo militar, o capitão Lemos, que jogava vôlei comigo na praia todos os domingos. No dia do golpe, ele me ligou e disse que o pau estava comendo feio, que os militares estavam tomando o Forte de Copacabana, que ele havia sido chamado para lá e, que se eu quisesse, eu poderia acompanhá-lo. Topei na hora. Ele me alertou que ele entraria sem problemas porque todos o conheciam, mas que eu poderia ser barrado. E se fosse, ele não poderia fazer nada. Decidi arriscar. Na entrada do forte, o sentinela bateu continência e o Lemos respondeu batendo continência e eu o imitei. Entramos. Nesse exato momento estava chegando o general Castelo Branco. O Castelo Branco estava chegando para passar o comando. Ele chegou com todo seu estado maior e eu comecei a fotografar. Os militares, inclusive o comandante do forte, achavam que eu o fotógrafo do Forte de Copacabana e me deixaram trabalhar. Chegaram até a fazer pose e me chamar para uma fotografia aqui, outra ali. E eu só fotografando, morrendo de medo, mas 
fotografando. Passado uns cinco minutos, o Lemos se aproximou de mim e falou: "Some daqui antes que eles nos descubram." E eu sumi o mais rápido que pude. Na realidade, fui o único jornalista brasileiro a fotografar o golpe pelo lado de dentro.

Paulo Boni-Qual foi o posicionamento inicial do Jornal do Brasil com o golpe?

Evandro Teixeira - Desde 1968, o Jornal do Brasil apoiava os estudantes e os estudantes tinham admiração pelo $J B$. Em 1968, a Cinelândia foi o grande palco de manifestações no Rio de Janeiro, especialmente dos estudantes. Era tudo por ali, Cinelância, Avenida Rio Branco, Candelária. Os estudantes, especialmente, paravam em frente ao prédio do Jornal do Brasil para fazer barricadas e enfrentar a polícia. Eles faziam isso porque contavam com o apoio do jornal. E para fotografar esses confrontos era fácil, dava para fazer tudo da janela, com um ângulo privilegiado de visão. Alguns manifestantes morreram nesses confrontos, pois a disparidade era muito grande: os estudantes enfrentavam a cavalaria com bolinhas de gude, para derrubar os cavalos, e a cavalaria não saía dos quartéis só para intimidar, não, ela descia o sarrafo. Alguns morreram vítimas de baionetas ou de bala mesmo. Resumindo: no início, os jornais foram favoráveis ao golpe, logo depois o Jornal do Brasil ficou do lado dos estudantes e estes protestavam contra o golpe.

Paulo Boni-Então era perigoso fotografar manifestações populares contra a ditadura?

Evandro Teixeira - Uma vez, durante uma manifestação, passamos em frente ao prédio da Embaixada dos Estados Unidos e os soldados começaram a atirar na gente, nos estudantes e em nós, jornalistas. Tenho algumas fotografias dessa manifestação. Nesse dia, tomaram a Leica do Erno Schneider que, na época, era fotógrafo do Correio da Manhã. 
Paulo Boni - O Erno Schneider foi ganhador do Prêmio Esso de Fotojornalismo, com aquela fotografia do Jânio Quadros com os pés enviesados.

Evandro Teixeira - Isso mesmo. Recentemente eu liguei para ele, pois precisava de ajuda para concluir um livro, uma biografia minha que eu e uma estudante estamos preparando. É um grande sujeito, muito meu amigo. Mas já está aposentado e não se lembra muito mais das coisas. Está pior do que eu (risos). Mas, voltando ao assunto, os policiais tomaram a câmera do Erno Schneider e partiram para cima de mim. Eu corri feito um louco, aliás, naquele tempo eu corria muito. Quando cheguei à Cinelândia eu ainda fotografei aquele estudante de medicina caindo. Ele bateu a cabeça no meio fio, em frente ao Teatro Municipal, deu um berro horroroso e morreu ali mesmo. E os policiais atrás de mim, mas não me pegaram não, eu corria muito mesmo, era bem magrelo. Veja que coisa: correndo da polícia, sem tempo de preparar a câmera para nada, consegui fazer uma fotografia que virou um símbolo da luta contra a ditadura militar no Brasil.

Paulo Boni - Você já apanhou muito por conta do seu trabalho?

Evandro Teixeira - Já levei muita bordoada, sim. Vivia sempre em perigo. Corri muito, às vezes eu conseguia fugir, às vezes apanhava, às vezes ia preso. Na cobertura da missa do Edson Luiz, aquele estudante que foi morto pela polícia, na igreja da Candelária, por exemplo, foi um massacre geral. A cavalaria chegou e arrebentou tudo, quebrou todo mundo, crianças, mulheres e velhos, sem distinção e sem piedade. Eu e outros fotógrafos estávamos no terceiro andar de um edifício próximo à Candelária e fotografamos aquilo tudo. A cavalaria nos viu e abriu fogo contra nós. Fomos expulsos à bala, tivemos que sair correndo pelos fundos e procurar abrigo em algum lugar. Fomos para o outro lado da Candelária, onde ficava o prédio da Seleções Reader's Digest. Era complicado e perigoso trabalhar. Os militares viviam nas redações. Uma vez um amigo meu, o Jacó, tomou a maior surra dos milicos. Quebraram sete costelas do Jacó. Ele passou três meses internado. 
Paulo Boni - Com todas essas retaliações - dentro e fora das redações -, como vocês faziam para trabalhar?

Evandro Teixeira - Tínhamos que usar a criatividade. Para driblar os censores, a gente preparava um contato preto, bem escuro, e como eles não sabiam fazer leitura visual, a gente dizia: "Não coronel, isso não tem nada de subversivo, não. É apenas uma comemoração do Dia das Mães..." Quando eles descobriram que estávamos querendo enganá-los, tomavam os filmes e dava muita confusão, mas normalmente só descobriam nossas mentirinhas no dia seguinte, quando as fotografias saíam publicadas. Quer um exemplo legal? Aquela fotografia das baionetas com as libélulas. Ela foi tomada em 1968, durante uma exposição de armas usadas na Guerra do Paraguai, inaugurada pelo presidente Costa e Silva. Ela foi publicada na primeira página do Jornal do Brasil, mas o general não gostou nem um pouco. Ele questionou o por quê dos "besourinhos", como chamou as libélulas. Mas acho que ele ficou mais furioso porque a fotografia das baionetas com as libélulas foi publicada grande, na primeira página, e a dele, inaugurando a exposição, foi publicada em tamanho menor, no interior do jornal. gina, e a dele, inaugurando a exposiira $\mathrm{p}$ a fotografia das baionetas com as lib ela pola o golpe.No dia seguinte, quando cheguei ao Palácio das Laranjeiras, alguém deve tê-lo avisado da minha chegada e ele mandou me chamar ao seu gabinete. Entrei, sentei e ele foi logo perguntando: "O senhor não me respeita, não é mesmo?" Eu levei o maior susto, e perguntei: "Senhor presidente, o que foi que eu fiz?" E ele: "Como é que você publica uns besourinhos na primeira página e a fotografia do presidente lá dentro, pequenininha?" Eu pedi desculpa e tentei justificar dizendo que era uma questão de edição, ao que ele prontamente respondeu: "Edição é o raio que o parta. Isso foi safadeza mesmo." E ordenou ao chefe de serviço que tirasse "esse moleque da minha frente".

Paulo Boni -Em razão de que circunstância ou de qual fotografia você foi preso?

Evandro Teixeira-Uma vez eu fui preso por conta de um general censor, que fotografei. Esse general era fã de um repórter do $J B$. Vou 
omitir o nome dele por razões éticas, mas nós o apelidamos de Marlon Brando, porque ele era jovem, bonito, parecido com o ator e gostava muito dele. De repente, esse general sumiu e o Marlon Brando foi visitá-lo e eu fui junto. Chegando à casa do general ele não queria me deixar entrar, mas acabou permitindo que eu entrasse junto com o Marlon Brando depois que o mesmo disse que eu não estava com equipamento e estava apenas de companhia. Ele estava só de pijama, na cama. Na cabeceira da cama, aquela cortina de renda, cheio de frufru. Eu sentei-me ao pé da cama, de forma escondida, ajustei o foco da Leica para dois metros e meio e, como ela não faz barulho nenhum e tem uma profundidade de campo espetacular, roubei umas três ou quatro fotografias. Ele nem percebeu. As fotografias ficaram muito boas e foram publicadas no dia seguinte com a legenda: O repouso do guerreiro. Quem foi repousar, na cadeia, fui eu. No período da ditadura era isso: prisões, pancadas e equipamentos quebrados ou apreendidos. Apanhei algumas vezes, fui preso outras vezes, mas, felizmente, nunca apreenderam ou quebraram meus equipamentos.

Paulo Boni - Você foi preso no episódio da Ilha das Cobras também?

Evandro Teixeira - Dessa vez não, por pouco. Fui à Ilha das Cobras para fotografar uns presos políticos. Eles (os militares) não os chamavam de presos políticos, e sim de subversivos. Lá estava, inclusive, um gerente do Banco do Brasil, que era comunista, e facilitou a entrada de revolucionários na agência que gerenciava para que eles roubassem o banco e conseguissem dinheiro para financiar a luta armada. Isso foi um escândalo porque, na verdade, de forma indireta, ele também era um ladrão, pois foi ele que armou o esquema para os revolucionários roubarem o banco, ele era conivente, era o mentor do assalto. No presídio, a gente tinha dois ou três minutos para fotografar os presos, sem poder falar nada com ninguém, tudo no maior silêncio. Quando eu entrei, levei o maior susto, pois entre os presos estava o Bira, um repórter do Jornal do Brasil. Fiquei nervoso, quis conversar com ele, intervir 
em seu favor, mas ele me balbuciou: "Faça suas fotografias e vá embora, se não ficaremos os dois aqui." Então, desse episódio eu escapei, mas o Bira não teve a mesma sorte.

Paulo Boni-Quem pautava essas fotografias? Por que os militares permitiam que elas fossem feitas?

Evandro Teixeira - Essas fotografias da Ilha da Cobras eram os próprios militares que convocam a imprensa. Na realidade eles queriam mostrar serviço para sociedade, queriam mostrar que haviam prendido uns subversivos, comunistas, bandidos.

Paulo Boni - E a intenção era, digamos assim, intimidar a população?

Evandro Teixeira - Isso mesmo. Na realidade, eles queriam era intimidar mesmo. Na realidade, de uma maneira ou de outra, eles queriam mostrar que todos os subversivos, comunistas ou bandidos eram presos, inclusive um gerente de banco. Eles prenderam muita gente: o Caetano Veloso foi preso, o João Saldanha foi preso, até o Bira foi preso. O Bira era um admirador fanático do comunismo, um falador destemperado... ele falava demais.

Paulo Boni - Ele não representava um perigo para o regime?

Evandro Teixeira - O Bira? Claro que não. Ele não era nada, não representava nada, apenas falava demais. Era um papagaio falador (risos). Eu tenho certeza que ele foi preso por falar demais. Eles prendiam por nada. Prenderam o Álvaro Caldas, que também era repórter do Jornal do Brasil. Massacraram o Geraldo Vandré por causa da música Caminhando. Essa música é maravilhosa. Estive na final do Festival de Música no Maracananzinho. Lembro como se fosse hoje, chorei muito naquela noite. Foi uma noite gloriosa, memorável. A música do Vandré concorreu com Sabiá, do Chico Buarque e do Tom Jobim, outra música maravilhosa, mas naquele momento ninguém queria saber de Sabiá, o clima estava mesmo era para Caminhando, porque ela focava e 
denunciava o momento político do país. E o Geraldo Vandré, coitado, sofreu muito, foi preso, torturado, pau-de-arara, o diabo. Ele ficou maluco.

Paulo Boni - Passado o calor da hora, a novidade do golpe, o Jornal do Brasil se posicionou de que forma? Continuou contra a ditadura militar? Passou a fazer autocensura? Como foi?

Evandro Teixeira - Não. O Jornal do Brasil cansou de ser preso, de sair em branco. Ele era censuradíssimo; os militares viviam lá dentro, moravam lá. No início, no primeiro momento do golpe, praticamente todos os jornais se manifestaram favoráveis aos militares. Mas depois eles foram mudando de opinião porque o próprio golpe mudou. Tanto é que até hoje pairam dúvidas sobre a morte do Castelo Branco naquele acidente aéreo inexplicável no Ceará. Muitos dizem que ele não morreu, mas foi morto. Outra morte até hoje inexplicada foi a da Zuzu Angel.

Paulo Boni - Todos acreditam que ela tenha sido assassinada pelo regime...

Evandro Teixeira-E foi mesmo. Ela lutou muito para esclarecer a morte de seu filho Stuart Angel, tanto no Brasil quanto nos Estados Unidos, e morreu por isso. O rapaz teve uma morte triste. Um dia eu recebi, anonimamente, uma fotografia dele morto. Alguém a mandou para mim. Eu fiquei apavorado. Levei a fotografia para a Zuzu e ela me disse: "Evandro, pelo amor de Deus, dá um sumiço nessa fotografia, leva ela lá para o jornal, some com ela." Eu a botei no arquivo do jornal. Se os militares me pegassem com aquela fotografia eu estaria ferrado. O Stuart estava em um estado deplorável. Eles pegaram o rapaz, o amarraram em um jipe e ficaram rodando com a boca dele amarrada no escapamento do jipe. Foi assim que eles o mataram, uma barbaridade!

Paulo Boni-Foram circunstâncias como essas que o fizeram lutar contra o regime?

Evandro Teixeira - Foram momentos terríveis e eu tinha que lutar contra aquilo. Minha arma foi minha câmera fotográfica. Com ela 
eu subi em palanques, entrei em palácios e em presídios, corri, apanhei, mas eu precisava registrar aquilo tudo, precisava deixar documentos para a história. Hoje eu estou aqui, contando minhas histórias e mostrando minhas fotografias. De alguma forma eu estou contribuindo para escrever a história desse país. Minhas fotografias serviram - e ainda servem - para mostrar um período do Brasil e o que eu pude fazer para reverter aquele estado de autoritarismo. A fotografia tem um papel muito importante para preservar e, às vezes, até mudar a história. Basta lembrar aquela fotografia da menina queimada, que ajudou a acabar com a Guerra do Vietnã. Então eu acho que, de certa maneira, ajudei a contar a história do Brasil.

Paulo Boni - E agora, com a tecnologia digital, você acha que a fotografia continua tendo um papel fundamental para preservar a história?

Evandro Teixeira - Continua, e muito. Eu diria que mais que a tecnologia digital, a crise do jornalismo no mundo inteiro interfere um pouco na fotografia, mas ela jamais deixou de ter - e continua tendo - um papel fundamental para o registro fiel da história. Eu faço parte do júri do Prêmio Esso de Fotografia e posso assegurar que, este ano (2011), havia muitas fotografias memoráveis. Foi muito difícil escolher uma dentre tantas fotografias excelentes.

Paulo Boni - Em 2010, a vencedora do Prêmio Esso de Fotografia foi a imagem de uma criança que acabou ficando cega pela subnutrição. Você acredita que hoje, com tanto acesso à informação, uma fotografia como essa pode contribuir para que alguma providência seja tomada pelas autoridades?

Evandro Teixeira - De certa maneira, sim. Eu acho que contribui sim porque a fotografia jornalística sempre teve esse papel fundamental de denunciar, de mostrar as feridas, as mazelas, as desigualdades. $\mathrm{O}$ problema é que o jornalismo, hoje, está dilacerado. No Rio de Janeiro, já chegamos a ter 19 jornais diários, hoje temos dois: $O$ Globo e $O$ Dia. 
Paulo Boni-E O Dia é um jornal sensacionalista...

Evandro Teixeira - Já foi mais sensacionalista, agora não é tanto. Mas $O$ Globo é um baita de um jornal, está na internet, fala o que quer, não sofre pressão. Mas a conta é desastrosa: cair de 19 para dois jornais é muito triste. Tínhamos o Jornal do Brasil, que foi o maior jornal desse país, o Correio da Manhã, que era maravilhoso, o Diário de Noticias, o Diário Carioca, O Jornal, o Diário da Noite, A Noite, o Tribuna da Imprens e outros. Hoje temos apenas dois, é muito triste.

Paulo Boni - Você acha que o fotojornalismo - e o jornalismo, por extensão - pode contribuir para que alguma coisa melhore no Brasil?

Evandro Teixeira - É difícil responder essa pergunta. Lamentavelmente, o país está dilacerado, a coisa está tão esculhambada, a expressão é essa mesmo, está uma falta de vergonha generalizada. O país está uma vergonha, é roubo para cá, corrupção para lá, um Deus nos acuda. Estou muito preocupado com a Copa do Mundo de 2014. Acho que vamos passar vergonha com nossos aeroportos, são muitas filas, muita demora, muita burocracia, taxistas brigando por passageiros nos saguões, uma vergonha. E o apresentador do Jornal Nacional reclama com aquele jeitinho de bom moço que não amedronta ninguém. Antes a imprensa tinha força de pressão, hoje não tem mais força nenhuma, pois está quebrada, dilacerada, esfacelada.

Paulo Boni - Muita coisa esfacelou, Evandro. Antigamente, uma greve tinha força, hoje não tem mais força nenhuma. Com a imprensa aconteceu a mesma coisa.

Evandro Teixeira-Claro, mas algumas coisas ainda surtem efeito, muitas coisas ainda são respeitadas. Se a imprensa consegue descobrir e denunciar alguma falcatrua, aquilo pode ser cobrado e resolvido pelas autoridades competentes, mas nem tudo. Antigamente a fotografia tinha mais força, mais poder; o jornalismo também tinha mais poder antigamente. Hoje, não temos a força que tínhamos antes. 
Paulo Boni - Você acredita que o jornalismo brasileiro tem repórteres fotográficos com competência e comprometimento para ocupar os espaços da velha guarda do fotojornalismo da década de 70 ?

Evandro Teixeira - Tem, tem sim. Mas não todos. Hoje, com tantas facilidades, o pessoal está se preocupando mais com a quantidade que com a qualidade. É claro que tem bons repórteres fotográficos trabalhando pelo Brasil afora, mas com o advento digital, vejo muita gente clicando e deletando automaticamente. Eu vou muito a jogos de futebol e vejo os repórteres fotográficos mais preocupados em clicar e deletar que prestar atenção no jogo, ou seja, eles acabam perdendo alguma coisa importante que acontece durante o jogo. Nos meus últimos anos de Jornal do Brasil, passei a exercer a função de editor de fotografia, que não me agradou nem um pouco, pois eu preferia estar nas ruas, no centro dos acontecimentos, no olho do furacão. Bem, mas o que eu quero contar é o seguinte: um garoto que tinha lá, muito bom de fotografia de esporte, aliás, foi fotografar uma final de campeonato de futebol e chegou à redação com mil e tantos fotogramas e deixou para eu editar. Fiquei puto da cara e disse para o sujeito editar ele mesmo o material: "Queime a pestana você. Eu é não vou queimar minha pestana em cima de tantas fotografias." Na época do analógico eram muito menos fotogramas para editar e com o "instante decisivo" mais bem evidenciado. Ou seja, hoje, ao que parece, a quantidade prevalece sobre a qualidade.

Paulo Boni - E o processo de edição, com tanta quantidade, não fere o deadline?

Evandro Teixeira - Vou continuar comentando esse mesmo caso. Enquanto o garotão ficou lá quase quatro horas em frente ao computador, selecionando trinta ou quarenta fotografias das mil e tantas que ele tinha, a Reuters encheu o computador da redação com boas imagens (já editadas) do jogo. A cada cinco minutos ela enviava novas fotografias. O operador me disse que havia uma "porrada" de fotografias da Reuters e perguntou o que ele deveria fazer. Eu disse: 
"Segura um pouco, não mande as fotografias para a editoria de esporte, ainda." Eu fiz isso para o garoto aprender que quantidade não resolve o problema; qualidade e agilidade, sim. Depois fui lá ajudá-lo a editar. Dei-lhe uma bronca e pedi para que ele prestasse mais atenção em seu serviço, pois ele faz parte de uma cadeia e muita gente fica amarrada por causa dele. Final da história: o editor de esportes usou uma fotografia da Reuters porque não podia esperar mais para fechar o jornal.

Paulo Boni - Você acha, então, que a tecnologia digital pode comprometer a qualidade do trabalho dos repórteres fotográficos?

Evandro Teixeira - É meio complicado afirmar isso. Acho que precisaremos de um tempo para que os repórteres fotográficos, por diversos motivos, descubram que facilidade não pode ser sinônimo de comodidade. Por enquanto, parece que tem muita gente deslumbrada, louca para mostrar seu brinquedinho novo. Certa vez eu fui cobrir uma solenidade com a presença do governador do Rio de Janeiro, o Sérgio Cabral, que, aliás, é muito meu amigo e o filho dele também gosta muito de mim. Quando o Sérgio estava chegando, um garotinho saiu correndo e um repórter fotográfico novato do jornal $O$ Globo começou a disparar fotografias insanamente, fez mais de cem fotografias de absolutamente nada. Eu até comentei com meus colegas que aquilo era pura babaquice, vontade de mostrar a câmera nova. Mas o fato é que hoje não há mais aquela coisa de apurar o olhar, critérios de seleção para só clicar no momento certo. Mesmo com tudo isso, claro, essa modernidade da tecnologia digital é maravilhosa. O Sebastião Salgado, que é um conservador em termos de fotografia analógica, filme preto e branco, somente recentemente mudou para a câmera digital; o Cristiano Mascaro, outro conservador, também aderiu recentemente à digital. Quero dizer, a tecnologia existe e é maravilhosa, mas é preciso ficar atento à pecinha que vai atrás do equipamento, ou seja, o fotógrafo. Ele é que irá fazer a diferença. 
Paulo Boni-Fugindo um pouco do fotojornalismo, você diria que o Brasil tem bons fotógrafos?

Evandro Teixeira-O Brasil é um berço de excelentes fotógrafos. A fotografia brasileira é uma das mais criativas e brilhantes do mundo.

Paulo Boni-Em termos de criatividade, de produto, de resultado, de ousadia, você acha que o Golpe Militar de 1964 e o AI-5 foram bons para os fotojornalismo?

Evandro Teixeira - Para o fotojornalismo, foram maravilhosos. Esta é uma bela pergunta, parabéns! Foram maravilhosos porque, primeiro, instigaram a criatividade, a busca de brechas para não só os repórteres fotográficos, mas todos os jornalistas, manifestarem subliminarmente seu inconformismo com o regime militar; segundo porque tivemos oportunidade de registrar um período conturbado da história do Brasil e deixar um legado para a sociedade, para essa garotada alienada que está aí estudando.

Paulo Boni - As fotografias desse período, de fato, ficaram para a história...

Evandro Teixeira -É impressionante a força dessas fotografias. Recentemente houve uma bienal de fotografia em Antuérpia, na Bélgica, e o curador da exposição veio ao Brasil escolher algumas fotografias para expor, pois o Brasil participa da bienal, e as fotografias minhas que ele escolheu eram todas da revolução. Ele justificou dizendo que elas conseguem recuperar aqueles momentos terríveis do Brasil. Ou seja, a fotografia tem esse papel fundamental, pois ela é um registro, um documento de época. O Arquivo Nacional acabou de fazer uma mostra fotográfica sobre o Brasil. Para essa mostra, recuperou coisas importantes de jornais que estavam presas, escondidas. Pediram algumas fotografias minhas do período da revolução. A maioria dos estudantes que pesquisam minha vida e obra me pergunta sobre o período da revolução. Aquela menina que está fazendo mestrado em Nova Iorque, que lhe falei, também estuda o período da revolução. 
Paulo Boni - O Arquivo Nacional, nós, na UEL, você, como fotógrafo, e mais uma série de instituições e organizações sabemos da importância da fotografia para a recuperação e preservação da história. Mas a fotografia que estamos utilizando para isso é a analógica. Será que vamos deixar documentos confiáveis para daqui a 50, 100 anos alguém contar a nossa história?

Evandro Teixeira-Bem, hoje existem meios de armazenamento. Você pode imprimir suas fotografias ou gravá-las em CD, DVD, pendrive, HD externo. Eu não sei se daqui a 100 anos seremos capazes de abrir esses arquivos. Além disso, eles são muito frágeis, suscetíveis de serem totalmente arruinados por um único arranhão num DVD, por exemplo. Eu me preocupo muito com a preservação de meu acervo, mas é claro que essa tecnologia, isto é, os estudiosos, estão pensando na preservação dessas imagens para o futuro. Por garantia, eu o tenho gravado em CD, em DVD e em HD externo. Mas sua preocupação procede, pois fica uma interrogação nisso tudo. Será?

Paulo Boni - Como fotógrafo há 47 anos... (o entrevistado interrompeu a pergunta)

Evandro Teixeira - 47 anos só de Jornal do Brasil. Na verdade eu comecei em 1958, no Diário da Noite. Em 1959 eu fiz uma viagem experimental de trem, com o Juscelino Kubistcheck, do Rio de Janeiro a Brasília, quer dizer Brasília ainda nem tinha ferroviária, fomos até Anápolis, em Goiás, e depois seguimos de jipe até Brasília. Essa viagem foi muito romântica, engraçada, cheia de travessuras: a gente parava para comer frutas, roubar leite de vaca, roubar galinhas. Meu início na fotografia foi muito legal.

Paulo Boni - Você ainda tem esse acervo?

Evandro Teixeira - Tenho parte. Eu tinha uma casa em Guaratiba (bairro da cidade do Rio de Janeiro), na qual havia uma outra casa, pequena, nos fundos. Na casa dos fundos eu guardei todas as minhas coisas, livros, revistas, negativos, fotografias. Deu cupim na casa e eu 
perdi muita coisa. Quando eu percebi, e isso já era tarde, fui mexer nas coisas e aquilo tudo desabou. Os danadinhos dos cupins comeram muita coisa. Eu tinha uma coleção completa da revista Photo, desde o número zero, e perdi tudo. Lá também estava uma série de matérias que eu fiz para o Diário da Noite sobre essa viagem de trem e tudo foi destruído. Agora, mandei pesquisar na Biblioteca Nacional para ver se recupero. Também havia materiais sobre a primeira Miss Brasília, a Martha Garcia, que era do Rio de Janeiro e depois se casou com o Justino Martins, que por muitos anos foi diretor da revista Manchete. Perdi isso tudo.

Paulo Boni - Voltando para complementar a pergunta anterior: nesses 53 anos de fotografia, você se arrepende de alguma coisa?

Evandro Teixeira - Não! Muito pelo contrário, adorei - e continuo adorando - minha vida de fotógrafo. Houve muitas situações extremamente gratificantes, algumas das quais eu já relatei nesta entrevista. Na década de 90, morei durante quatro anos no sertão de Canudos para produzir o livro Canudos, 100 anos. Foi uma experiência única, linda, gratificante. Minha avó me contava muito sobre Canudos. Eu praticamente nasci com Canudos na cabeça e depois que eu morei lá, meu caro amigo, eu volto todo santo ano para Canudos. É uma história maravilhosa, que ficou e ficará para sempre em meu coração. Você acha que dá para se arrepender de uma oportunidade como essa? Só não fui esse ano (final de 2011), por causa desse problema no joelho. Estava tudo pronto para a viagem. Iríamos eu e mais dez alunos, mas esse problema no joelho me obrigou a cancelar a viagem. Eu continuo fotografando cada dia mais. Nem penso em parar de fotografar. Mesmo que eu ganhe a mega sena, jamais deixarei de ser fotógrafo. Pelo contrário, me tornaria mais fotógrafo ainda e iria fazer só aquilo que tivesse vontade, como publicar livros. Eu tenho sete livros publicados e quero publicar outros, inclusive um autobiográfico. Agora no final de 2012 espero finalizar e publicar a terceira edição, atualizada, de Fotojornalismo. Quanto ao livro de minha biografia, a Silvana Costa Moreira, uma jornalista baiana, e o Marcos Eduardo Neves (autor da 
biografia do Heleno, ex-jogador do Botafogo, que agora virou filme com o Rodrigo Santoro) estão terminando para novembro pela editora Casa da Palavra. Hoje, aos 76 anos, tenho muita força, muita vontade de continuar fotografando; eu não quero parar.

Paulo Boni - Você disse que iria para Canudos com seus alunos. Você está dando aulas de fotografia?

Evandro Teixeira - Estou com um curso de fotojornalismo na ABAF - Associação Brasileira de Artes Fotográficas. Independente disso, ofereço workshops de fotografia documentária em lugares típicos ou históricos do Brasil. Já havia uma turma certa para Canudos. Também havia uma turma certa para o Santuário de Aparecida, que eu também cancelei por causa do joelho.

Paulo Boni - Você se considera reconhecido pela sociedade brasileira, como agente construtor e transformador da história?

Evandro Teixeira - Eu me sinto muito feliz. Pelo menos pelos estudantes de fotojornalismo eu sou muito procurado. Modéstia à parte, eu sou uma fonte de informação para os estudantes de jornalismo. Eu me sinto feliz, importante, reconhecido. Há dois anos eu fui para os Estados Unidos participar de uma exposição na Galeria Leica. Só havia dois brasileiros participando, eu e o Sebastião Salgado. Isso é uma honraria muito grande para mim. Acho que o Brasil ainda é um país que não valoriza sua gente. $O$ Brasil tem o péssimo hábito de elogiar o estrangeiro. O Sebastião Salgado, por exemplo, é muito mais reconhecido e valorizado no exterior que em seu próprio país. Mas, na medida do possível, eu me sinto reconhecido, respeitado e feliz. Outra experiência muito gratificante foi o livro 68 destinos - passeata dos $100 \mathrm{mil}$, que considero um instrumento importante para contar a história daqueles que lutaram pela democracia no Brasil. Foi fantástico, depois de tanto tempo, localizar essas pessoas, conversar com elas, fotografálas individualmente. Essa alegria, meu amigo, essa sensação de dever cumprido, não há dinheiro que pague. 
Paulo Boni-Evandro, eu me esqueci ou deixei de perguntar alguma coisa importante?

Evandro Teixeira - Não. Mais que isso eu me tornaria repetitivo, se é que já não fui. O importante mesmo é que eu estou aqui, estou com uma pessoa que luta pela fotografia, que valoriza a fotografia, que ensina fotografia aos mais jovens e estou muito feliz por estar aqui. O que realmente importa, meu amigo, é aprender um pouco a cada dia. Eu não vim aqui para ensinar, vim para aprender, e aprendi muito. Eu sou apenas mais um que ajudou a construir a história do Brasil com sua fotografia, e que continua ajudando, mas continua aprendendo, porque a fotografia é um eterno aprendizado. Ninguém é dono da verdade e eu sou apenas mais um aprendiz naquilo que a gente gosta de fazer, que é a fotografia.

Paulo Boni - Muito obrigado.

Evandro Teixeira-Muito obrigado, também. 